\title{
Economy-wide impact of TPP: new challenges to China
}

\author{
Chandrima Sikdar ${ }^{1 *}$ (D) and Kakali Mukhopadhyay ${ }^{2,3,4}$
}

\author{
*Correspondence: \\ chandrimas4@gmail.com; \\ chandrima.sikdar@nmims.edu \\ ${ }^{1}$ School of Business \\ Management, Narsee Monjee \\ Institute of Management \\ Studies, V. L. Mehta Road, \\ Mumbai 400056, India \\ Full list of author information \\ is available at the end of the \\ article
}

\begin{abstract}
The Trans-Pacific Partnership (TPP) agreement as originally announced in October 2015 was undoubtedly the largest regional trade accord in history and, if approved, could have set new terms for the nearly US $\$ 28$ trillion in trade and business investment between the parties to the deal. But the deal hit a roadblock when the USA decided to withdraw from the agreement in January 2017. While some of the countries are interested in taking the TPP forward without the USA, there are others which are still looking at convincing the USA to reconsider its position on the deal. Thus, while all the debate and deliberation around the prospect of TPP continues, an important point to note is that the TPP deal does not include China, world's largest merchandise trader, which had combined exports and imports worth US $\$ 3963.5$ billion in 2015. Against this backdrop, the present paper seeks to analyze the impact of the TPP agreement on various trade and other economic variables of China both if the USA continues to be a part of TPP and if the USA withdraws from TPP using the Global Trade Analysis Project. The unique contribution of the present study lies in analyzing the trade integration scenarios among the TPP member countries involving all of tariff and non-tariff liberalization and improved market access between the countries, without the USA. The results indicate that China's trade with TPP region, both exports and imports, will suffer post-TPP implementation. Exports which are likely to be hit are leather and leather products, motor vehicles, meat products, processed food, iron and steel. Imports of oilseeds, paper and paper products, nonmetallic minerals and machinery are also expected to suffer. More than the loss in trade, China will experience substantial welfare loss due to all of allocative inefficiency, worsening terms of trade and endowment effect. Of these, worsening terms of trade explain the largest part of welfare loss to the country. With the withdrawal of the USA from the deal, China's trade with the region and its welfare is likely to suffer less.
\end{abstract}

Keywords: TPP, China, CGE modeling, GTAP, Trade, Welfare

JEL Classification: F14, F15

\section{Introduction}

The negotiations on TPP were concluded on October 4, 2015, by 12 Pacific Rim countries, namely Australia, Brunei Darussalam, Canada, Chile, Japan, Malaysia, Mexico, New Zealand, Peru, Singapore, USA and Vietnam. The scope of this new generation comprehensive trade agreement covered the traditional barriers to trade in both goods and services, investment and other trade-related areas. These areas referred to formal

(c) The Author(s) 2017. This article is distributed under the terms of the Creative Commons Attribution 4.0 International License (http://creativecommons.org/licenses/by/4.0/), which permits unrestricted use, distribution, and reproduction in any medium, provided you give appropriate credit to the original author(s) and the source, provide a link to the Creative Commons license, and indicate if changes were made. 
restrictions related to trade and investment activities, intellectual property rights, labor and environmental standards and issues and challenges related to digital technologies. In this form, the TPP deal could be the most important trade and investment pact that the world has witnessed since the creation of World Trade Organization (WTO) more than two decades ago (Schott 2013).

The TPP agreement as signed in October 2015 appeared largely different from the several FTAs signed and implemented across the world in recent times. Some of the features which set this TPP agreement apart from the other trade agreements are:

First, in terms of economic footprints in the world its members account for way larger share than those by most other recent trade agreements. The 12 member countries together account for $37.4 \%$ of world GDP, $11 \%$ of world population and $26.3 \%$ of total world trade in 2015 . The intra-TPP trade accounts for $15.5 \%$ of total world trade (Table 1).

Second, in terms of scope and coverage and depth of commitments to trade liberalization it is one of the most comprehensive trade agreements and that too involving both developed and developing countries. The implementation of the agreement is likely to lead to increased trade and investment opportunities in goods and services and increased market access among the member countries by lowering tariffs and easing the non-tariff barriers. Requirements like imports licensing, quality standards, custom rules, pre-shipment inspections and rules of origin which are often obstacles to free trade come within the scope of non-tariff barriers. TPP is set to encourage greater coherence in standards and regulations among its members. The existing tariff between the TPP member countries has come down significantly over the years from around 5.8\% in 1996 to $2.8 \%$ in 2014 (Global Economic Prospects 2016) and is substantially low compared to international standards. The same is true for non-tariff barriers existing in these countries. These are due to the various other trade agreements, like NAFTA and ASEAN, that got created between the different members countries of TPP. Yet the TPP is set to lower

Table 1 Economic profile of TPP 12, 2015. Source: World Bank; UN COMTRADE database

\begin{tabular}{lrrlll}
\hline TPP member & $\begin{array}{l}\text { GDP (billion } \\
\text { US \$) }\end{array}$ & $\begin{array}{l}\text { Population } \\
\text { (millions) }\end{array}$ & $\begin{array}{l}\text { Merchandise trade } \\
\text { with world (billion } \\
\text { US \$) }\end{array}$ & $\begin{array}{l}\text { Merchandise trade } \\
\text { with TPP 12 (billion } \\
\text { US \$) }\end{array}$ & $\begin{array}{l}\text { TPP trade as \% } \\
\text { of world trade }\end{array}$ \\
\hline Australia & 1339.5 & 23.8 & 388 & 231 & 60 \\
$\begin{array}{l}\text { Brunei Darus- } \\
\text { salam }\end{array}$ & 15.5 & 0.4 & 9.5 & 5.7 & 60 \\
Canada & 1550.5 & 35.9 & 828 & 633 & 76 \\
Chile & 240.2 & 17.9 & 126 & 67.9 & 54 \\
Japan & 4123.3 & 127.0 & 1250 & 650 & 52 \\
Malaysia & 296.2 & 30.3 & 376 & 202 & 54 \\
Mexico & 1144.3 & 127.0 & 776 & 633 & 82 \\
New Zealand & 173.8 & 4.6 & 70.9 & 43 & 61 \\
Peru & 192.1 & 31.4 & 71.3 & 40 & 56 \\
Singapore & 292.7 & 5.5 & 643 & 290 & 57 \\
USA & $17,947.0$ & 321.4 & 3811 & 2155 & 50 \\
Vietnam & 193.6 & 91.7 & 328 & 164 & \\
\hline
\end{tabular}


these tariffs further and eliminate it completely by 2046. However, the countries are allowed different phasing out periods for their tariff and non-tariff liberalization (Fig. 1).

Along with providing comprehensive market access to member countries by reducing tariff and non-tariff barriers, the TPP also aims at helping the development and deepening of supply chain among the member countries. The countries of the region have for a while been active participants of the worldwide supply chain integration as is indicated by the share of foreign value added in their exports which range from $15 \%$ in advanced countries of Australia, the USA and Japan to $40 \%$ in the developing countries of Malaysia and Singapore (Fig. 2). Facilitating these supply chains within the region calls for good physical connectivity through ports, roads along with policies that facilitate trade in intermediate goods and services and foreign investment. Thus, along with lowering of tariff and non-tariff restrictions, TPP is also likely to bring down the trade costs such as customs fees, port handling charges and the cost of time in trade between the member countries.

The TPP, when announced, was undoubtedly the largest regional trade accord that history could have witnesses and, if approved by the member countries, it would have set new terms for the nearly US $\$ 28$ trillion in trade and business investment between the parties to the deal. But this TPP deal hit a road block with Donald Trump winning the Presidential election in the USA in November 2016. Former US President Barack Obama treated trade deals as a priority during his tenure. And TPP was expected to bolster the position of the USA in the Asia-Pacific region, where China's influence was growing by

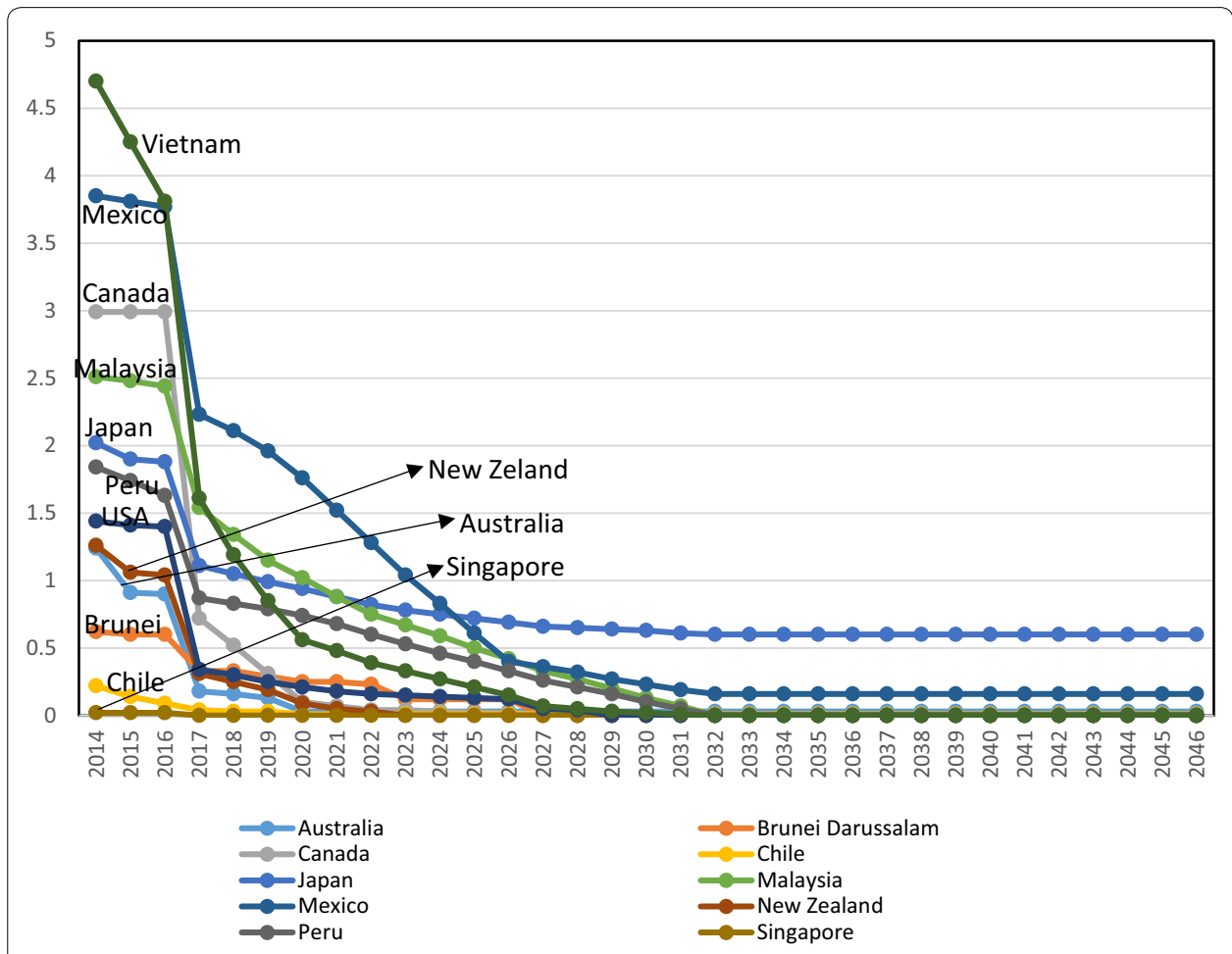

Fig. 1 Average intra-tariff (percent) of TPP countries (USA included) over time (2014-2046). Source: based on data from ITC Market Access Map database (available at http://www.macmap.org) 


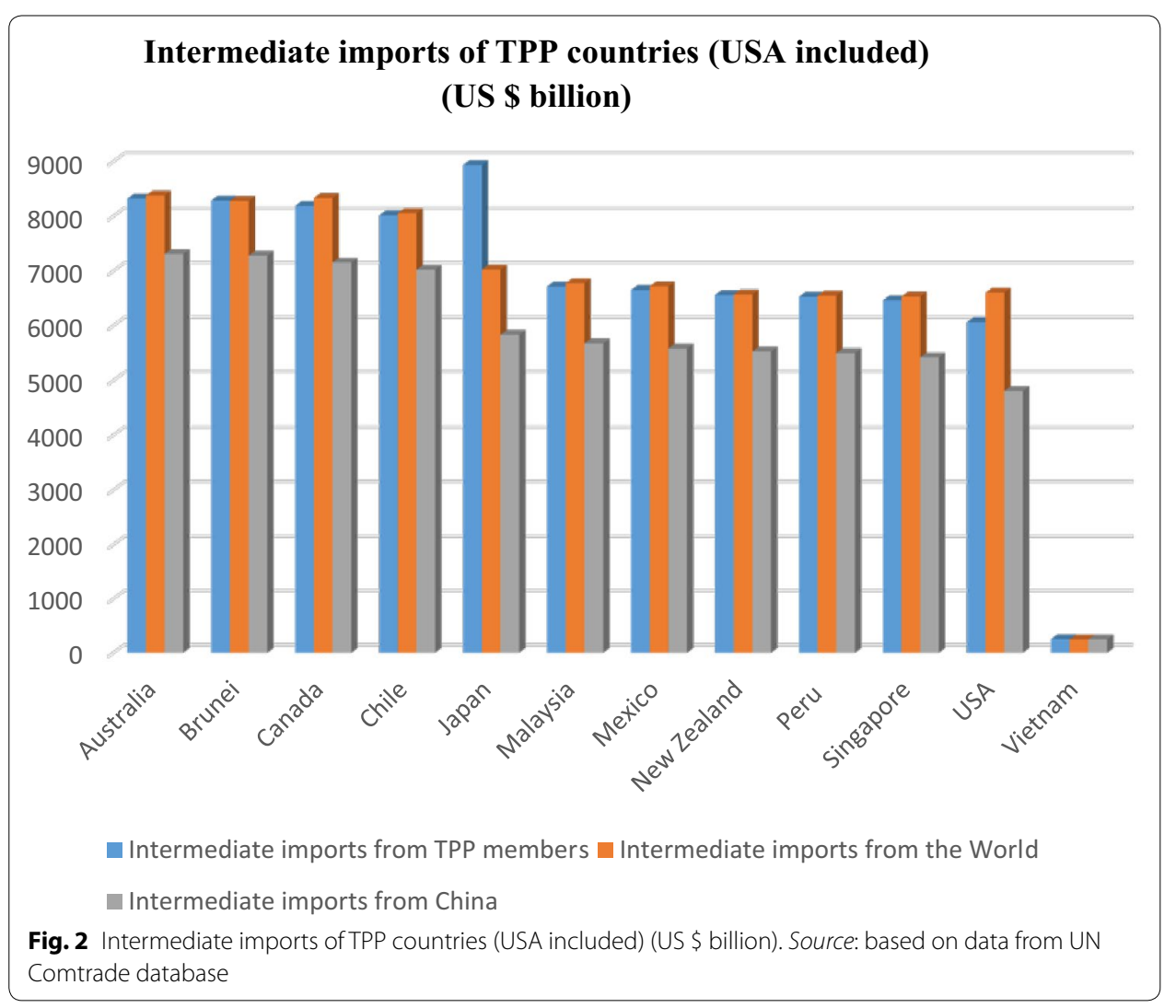

the day. But in Trump's words this was a "horrible deal" that would favor big businesses and other countries at the cost of job's and national sovereignty in the USA. Accordingly, on January 23, 2017, Trump signed the executive order which formally withdrew the country from the TPP trade deal. It has been largely held that this move by the President of the USA has effectively killed TPP for the other member countries too. However, some negotiating countries have still shown interest in taking this deal forward without the USA. At the same time, other countries, like Japan and Canada, are reluctant to move ahead and are currently looking at convincing the USA to reconsider its position on the agreement. The prevailing thought is that the TPP in its current form is dead and the other eleven countries must now form new deals. Thus, while all the debate and deliberation around the prospect of TPP continues, an important point to note is that the TPP deal does not include China, world's largest merchandise trader, which had combined exports and imports worth US \$3963.5 billion in 2015 (UN Comtrade). So the obvious question that arises is-What does TPP mean for China with the USA or without the USA?

China routinely denounced the TPP till about 3 years back and held that it is possibly one of the many efforts to contain China. However, of late, China has given up this blanket opposition and has adopted a more nuanced attitude of "wait and see" (Naughton et al. 2005). Thus, though currently, China may not be ready to meet the demanding requirements of the TPP agreement but possibly might join the group in a few years 
from now. ${ }^{1}$ Particularly, given the current status of the deal, there may be the potential for China to join it soon.

Thus, the implications of the TPP on China do call for an in-depth study. The present study aiming to do this begins by investigating the pattern of China's current trade with the TPP member countries. Thus, the rest of the paper is organized as follows: Sect. 2 presents a discussion of China's trade with the TPP member countries. Section 3 discusses the methodological framework. The data are discussed in Sect. 4. Section 5 presents the results. The paper finally concludes in Sect. 6 with a summary of the findings and their policy implications.

\section{China's trade with the TPP region}

China's trade with the TPP region accounts for $49 \%$ of China's overall goods trade with a trade surplus of US $\$ 337$ billion in 2015 (UN Comtrade). Its trade in the region is concentrated in the USA, Japan, Vietnam, Singapore, Malaysia, Australia, Mexico and Canada. Excepting Mexico, these countries are both top export destinations and top import sources for China. Mexico is an important export market. These countries account for $97 \%$ of China's total export to the region and $45 \%$ of China's total import from the region (Figs. 3, 4).

At the aggregate level, the largest category of China's exports to TPP countries is machinery and mechanical appliances; electrical machinery and equipment; furniture, mattresses, cushions and other stuffed furnishings; articles of apparel and clothing accessories; articles of iron and steel; optical, photographic, cinematographic equipment; plastic and articles of plastic; vehicles other than railway or tramway rolling stock and their parts; ships, boats and floating structures; mineral fuels, mineral oils and products of their distillation; and toys, games and sports requisites. Almost all of these products are subject to import tariff by the importing country with some of the products like apparels and clothing accessories, vehicles and vehicle parts, fibers subject to substantially high import duties (Tables 4, 5).

Many of China's exports to these countries are also subject to non-tariff barriersmostly technical barriers to trade (TBTs). Particularly, the USA and Canada impose these TBTs on several electrical appliances, like refrigerating appliances, water and gas heaters, dishwashers, washing machines, fluorescent lamps, batteries, air conditioners and radio communication equipment which they import from China. The USA also imposes specific TBTs on children products imported from China. Imports of textile products from China are subject to such TBTs by Canada. Japan imposes these technical barriers on import of wooden furniture and construction machines from China. China also on its part applies several such non-tariff barriers to its imports in the form of licensing requirements and TBTs to all its partners including the TPP countries (WTO).

Against this backdrop, the present paper seeks to analyze the immediate impact of this TPP agreement on China's trade position and examines its consequence for the country's welfare position. This impact analysis is done for both the situations-one, where the USA is part of the TPP as it was originally supposed to be, and two, when the USA is

${ }^{1}$ The TPP is designed as a "living agreement" to allow for membership expansion as well as broadening of coverage (Global Economic Prospects 2016). 


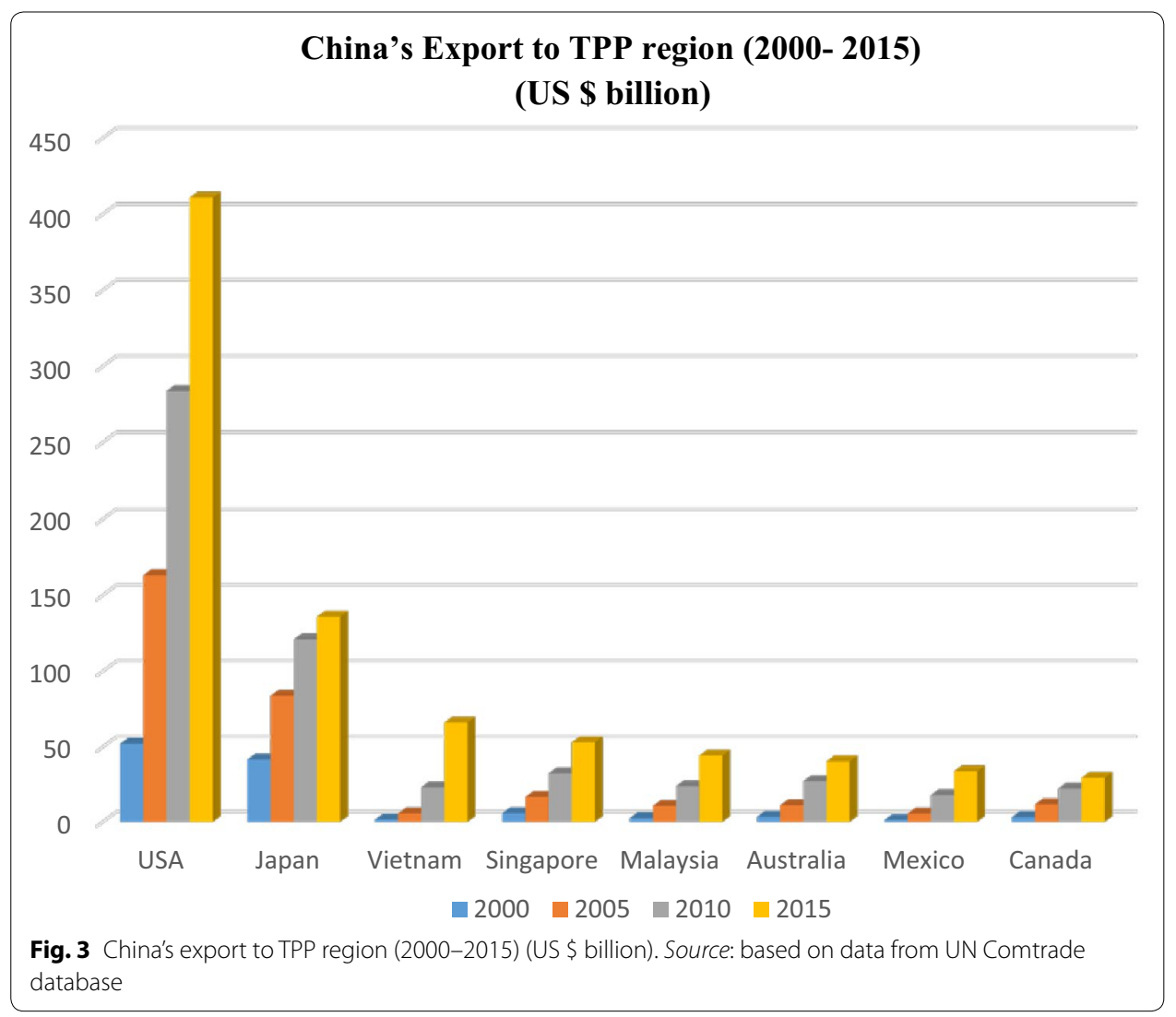

not a part of it as the situation is likely to be now. This would enable one to compare the impact of the trade accord on China in both the situations and, thus, could come up with important insight into the prospects and potential of China joining the deal any time soon. The study resorts to an applied general equilibrium (AGE) analysis for this purpose. It uses the Global Trade Analysis Project (GTAP) ${ }^{2}$ and does a number of simulations through GTAP data by calibrating various trade integration scenarios between the 12 TTP countries and studies the impact of the agreement on China.

The TPP addresses certain barriers to trade, which as of now have not been dealt so extensively in any other trade deal. While the hope of a sustained participation of the USA in Asian development stirred the deal, what also remains to be understood is the vast array of debates that followed to unearth the participation/non-participation connotation of China in TPP. This debate has further taken new directions with the withdrawal of the USA from the deal. This has been substantiated with huge researches and studies, each complementing their own (and differing) objective question.

To begin with a contemporaneous outlook on the analysis, Ghemawat (2016), explores the implication of abandonment of TPP and subsequent trade relations between China and the USA. The dumping of TPP would mark an end to the pivotal inclinations of USA towards Asia, however, not affecting the security agreements Japan and South Korea 


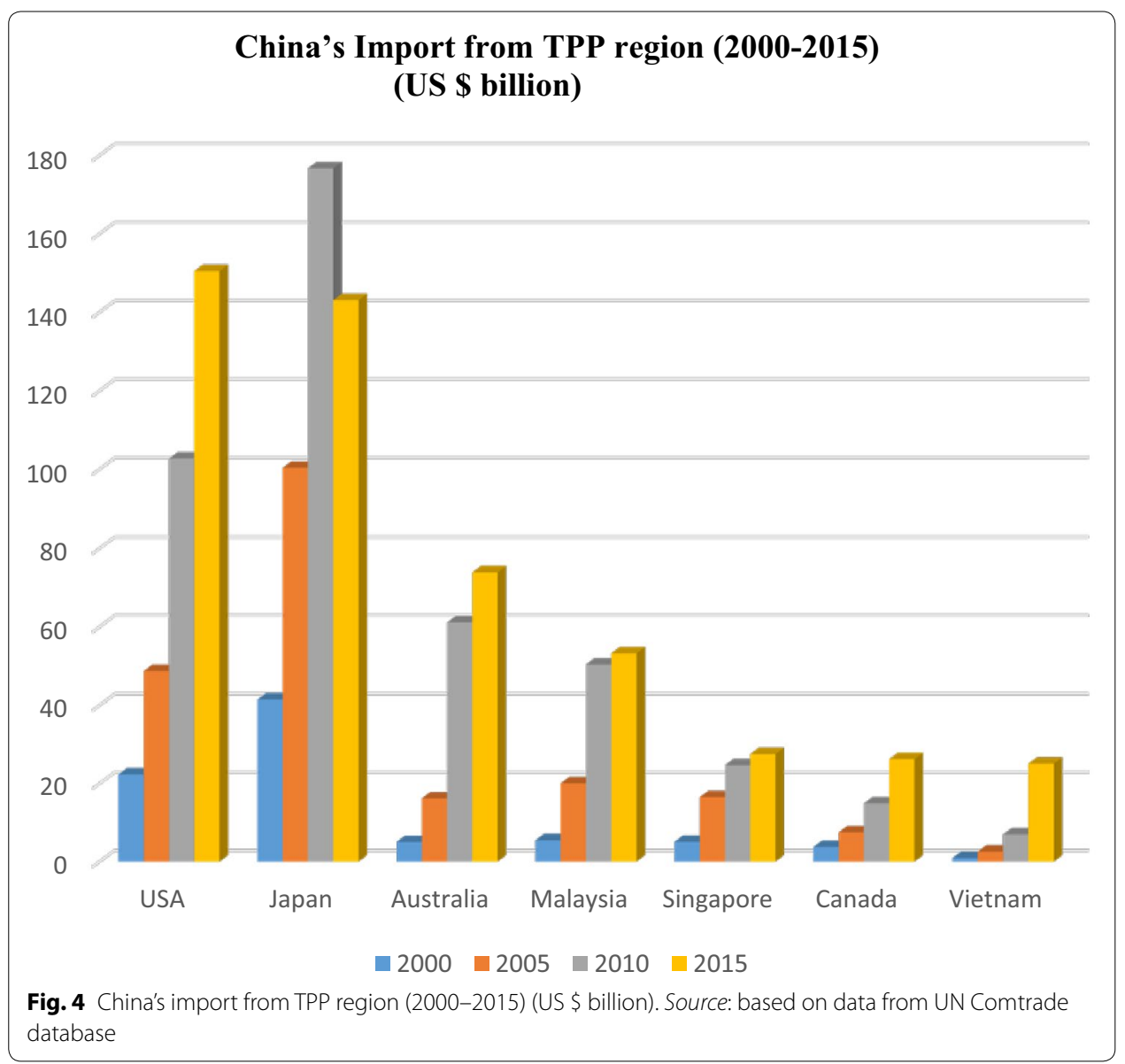

share with the USA. If the current security relationships are solely guided by economic concerns, then a possibility of a paradigm shift in the economic interests provides a dual possibility of strengthening as well as weakening of these security ties. The shift of certain Asian nations to the USA becomes more of a security for hire rather than a security guarantor in absolute terms. This gradually invokes a new geopolitical mapping, with not very pleasant results for the USA, as old alliances fall apart. Given the vast (leading and dominant) display of trade patterns attributable to China at a global level, the calling off of TPP would be in advantage to China.

As per the analysis, which is substantiated by Schott (2013), China will be benefited if TPP is enforced because it promotes economic growth in the region, which is good for trading. Rosenfeld (2016) also argues on the same line and holds that collapse of TPP could be bad for all countries involved including China. Sumpter (2016) too believes that loss of TPP is a loss to China because of the interest China was showing silently in TPP. Contrary to this, Llosa (2016) remarks that the "TPP will do little, if anything, to slow the growth of China's economic and political power" because the trade pact "is irrelevant to China."

The topic of TPP, its impact, inclusion or exclusion of China in the agreement has given rise to a number of formal researches too. Petri et al. (2016) explain through global computable general equilibrium (CGE) model the impact of TPP on the partner countries 
and the USA. The estimate is that the annual income in USA will increase about $0.5 \%$ of GDP baseline by 2030. It will also benefit the members, following its execution. As such, a 1-year delay in the implementation of TPP will result in permanent real income loss ranging from US $\$ 77$ billion to US $\$ 123$ billion for the USA. The loss to the other countries is likely to vary from US $\$ 308$ billion to US $\$ 525$ billion. The results show that if trade barriers are relaxed, it would lead to an efficient reallocation of labor and capital. This would also enhance productivity, with a subsequent rise in income and wages. In addition to this, TPP has developed on broad rules, which are much more lucid and descriptive than WTO. It includes services, telecommunications, digital economy, investment and other critical industries. TPP is seen as a pathway to Free Trade Area of Asia Pacific. This would not only promote gains for the USA, but also promote integration in Asia Pacific region and beyond. As such, it is also reflective of a rule-driven global economy.

Xin (2014) does a recursive dynamic CGE modeling exercise to simulate two scenarios against the baseline, namely a TPP agreement with China and the one without China. The results indicate that small countries like Vietnam will benefit if they join the trade agreement with China, while the TPP with China will not change the fundamental geographical makeup of markets or the role in the integration of Southeast Asia with China. An integration that spans Asia Pacific will, in all regard, benefit the USA.

Schhot (2013) appraises the larger framework of functioning of TPP and the implication it has on its member states. In context of China, the TPP has important results for the economic relations between the USA and China. Chinese officials have engaged in considerable research related to the dynamics of TPP impact on Chinese economy and the subsequent challenges it would face. Non-participation on the part of China would mean a loss of exports worth US $\$ 100$ billion.

Schhot (2013) also explores the political machinations of trust at work between Beijing leaders and Washington. This has time and again reflected in certain ways, biannual US-China Strategic and Economic Dialogue being one of them. Though China may not be ready to accept the large array of TPP obligations related to transparency and discipline related to government intervention in the market, China's increasing efforts toward aligning to TPP standards are much apparent in two major ways. One is its constructive efforts toward domestic economic reforms and the other is its participation in plurilateral trade agreements and in FTAs and bilateral investment treaties. But TPP obligations do also pose great challenges to China in the form of labor rights, freedom of data flows and intellectual property. Thus, China has for some time been weighing these challenges that TPP obligations are likely to pose to its policies and competitiveness as against new opportunities that TPP could fetch for it. Though uncertainty lingers as to whether China would amend its trade policies like Vietnam, in a definitive conclusion, if TPP expands to other key Asian trading partners, China would have to reconsider its stance on TPP membership. One of these options would include deepening its economic engagement with the USA, which includes efforts under way in APEC to build a Free Trade Area of Asia Pacific (FTAAP).

Petri et al. (2012) examine the strategic benefits and incentives generated by TPP agreement and FTAAP over 2010-2025. Initially, the world would have a small gain, but by 2025 the annual welfare gains would be US $\$ 104$ billion on the TPP track and US 
$\$ 862$ billion with the FTAAP track. Though these tracks will be competitive, their implications are constructive. Thus, their pathway will generate incentives for enlargement, for both the USA and China. Conducting simulations using a CGE model of world economy as developed by Zhai (2008), the results indicate that though the pace of progress is uncertain, the direction is compelling. The most vivid scenario that emerges is that the tracks emerge parallel and then ultimately consolidate. Overall, the agreement would result in lower costs and greater gains for both the USA and China in the future than it would in its immediacy.

The present paper relates to a number of existing researches. It relates to the empirical work on TPP involving China and other countries as also to the kind of modeling exercises involving impact of TPP on the member countries and China. But there are a number of points on which the present paper differs from the already existing literature on the topic.

The present paper focuses on analyzing the impact of TPP (with and without the USA) on China using a CGE modeling exercise. Schott (2013) does a comprehensive discussion on the features of TPP and reflects on its possible implementation for China, but his study is not based on any model building exercise. Petri et al. (2016) use a CGE model to analyze the implications of TPP but for several countries/regions-America, Asia, Oceania and Rest of the world. Impact on China is discussed as part of its discussion on Asia. Xin (2014) focusses on impact on China and also uses a CGE modeling exercise. He considers two liberalization scenarios: one with China and the other without China. But the study considers full tariff liberalization unlike the present study which looks at the implications of the TPP for the members and China taking into account the actual phased tariff liberalization commitments of the member countries. The study further does two more simulations-first, a scenario where the developing member countries experience input augmenting technical changes due to the likely development of production networks within the region and second, the improvement in trade costs between members, particularly the developing countries. Given its scope and coverage, TPP is one of the most comprehensive trade deals of recent times. It includes not only tariff liberalization but also easing of non-tariff barriers like custom rules and pre-shipment inspections. Thus, an analysis of its impact based only on tariff liberalization is rather an incomplete analysis. The present study seeks to fill this gap by calibrating various trade integration scenarios involving tariff and non-tariff liberalization and improved market access between the members of the TPP agreement. Besides, all the studies by Schott (2013), Petri et al. (2016) and Xin (2014) consider the TPP deal in its original form where the USA was one of the negotiating countries. There is no study which discusses the impact of TPP, without the USA on China to the best of the knowledge of the present researchers. The present study contributes toward filling up that gap too.

\section{Methods}

The computable general equilibrium (CGE) modeling framework is one of the best possible ways to analyze ex ante the economic consequences of multilateral and bilateral trade agreements. Any comprehensive analysis of trade issues should involve an analytical framework which captures not only the inter-linkages existing between the sectors of an economy but also the linkages present between these sectors and the rest of the world 
by way of exports and imports of final products, intermediate goods, capital goods and so on. The CGE framework integrates these linkages present at the national, regional and global level in both product and input markets.

A CGE model comprises of a system of equations that describe an economy and the interactions among its various parts. All equations in the model are solved simultaneously to find an economy-wide equilibrium in which, at some set of prices, the quantities supplied and demanded are equal in all markets. Thus, all producers, consumers, workers and investors in the economy are satisfied with the quantities of goods they produce and consume, the number of hours they work, the amount of capital they save and invest and so on. The equilibrium in the CGE models satisfies important macroeconomic and market clearing constraints like equality of aggregate supply and aggregate demand for goods and services, full employment of labor force and capital stock and equality of national or global savings to investment. These models begin with classifying variables in the equation as exogenous and endogenous variables (Burfisher 2012).

Experiments in CGE modeling framework involve shocking the exogenous variables, after which the model equations are re-solved to yield new solution values for all the endogenous variables. The new values represent new equilibrium in which supply in all markets across the economy once gain equals demand at some new set of prices. The results obtained from the simulations are comparative static results. Thus, the models study the impact of the changes in exogenous parameters (shocks) on allocation of goods among consumers and resources among productive activities and also the consequences for economic efficiency. Alternative equilibrium states are compared without considering the path between the two states. Thus, the models do not have explicit time dimension. They represent different time frames by changing the microeconomic elements of the closure. The results of static simulations are often interpreted as representing how an economic system would look if the new policy had been in place in the base year, after relevant adjustments had taken place (Gilbert 2001).

The present study uses the global CGE model database developed by Global Trade Analysis Project (GTAP) which provides the core datasets required by CGE models. These data include input-output tables, bilateral trade flows, transport costs, information on tariff and non-tariff barriers and all other data that are in the Social accounting Matrices (SAM) and used in CGE models (Burfisher 2012).

The exogenous variables in a standard GTAP model are such that there is full employment in the factor markets. This is a neoclassical approach whereby the endowments of the productive factors are fixed allowing market prices to adjust so as to ensure full employment always. But full employment is far from true in the real world, particularly for unskilled labor force and that too in developing countries. Thus, to capture the real-world scenario, the simulations conducted in this study replace the assumption of full employment of the standard GTAP model with existence of unemployment of unskilled labor force for all the countries/regions under consideration. This is done by swapping the fixed endowment of unskilled labor in all of China and the developing countries of the TPP region and the rest of the world with fixed real wage of unskilled labor. Thus, market prices of unskilled labor no longer adjust to establish full employment, but instead capture the unemployment with respect to unskilled labor in each of the economies. 
To study the impact of the TPP on trade and other economic variables of China, the present paper does a number of simulations through GTAP data by calibrating various trade liberalization scenarios between the TTP countries. The simulations broadly include the following scenario where:

- Existing tariffs on goods between the member countries are first reduced so as to capture the liberalization scenario in 2020 and then the scenario in 2046-the year by which countries would complete their tariff liberalization commitments. The tariff reductions are based on the tariff commitments of the countries as available from ITC Market Access Map. ${ }^{3}$

- Goods traded extensively as inputs between the member countries, in particular, import of inputs by developing from the developed countries are identified and the sectors in the importing developing country using these imported inputs are shocked so as to show the effect of an input augmenting technical change. This simulation aims to capture the impact of deepening production and supply chain within the TPP region. In this case too, the tariff reductions are based on the tariff commitments of the countries as available from ITC Market Access Map

- Reduction in trade costs such as customs fees, port handling charges, and informal payments and the cost of time in trade between the member countries. These costs are incorporated in the CGE modeling framework of GTAP as tariff equivalents.

Each of these exercises is done both with the USA and without the USA included as a member country.

For more detailed understanding of the GTAP modeling framework and its application in the present study, refer "Appendix 1."

\section{Data}

The database used here is the latest version 9 of the GTAP database (Global Trade Analysis Project, Purdue University) which has 2011 as the base year. The database is compiled for bilateral exports and imports and tariffs inclusive of other flows for 140 regions across the world and for 57 tradable commodities of the world. The present study aggregates these 140 regions into 14 regions and the 57 sectors into 22 sectors (see "Appendix 3 "). The database has been updated to reflect the world economy in 2014 by applying macroeconomic shocks - changes in the values of the macroeconomic variables (GDP, population, skilled and unskilled labor and capital). The recursive updating process is based on forecasting for the economies and the regions by exogenously shocking the baseline model with projections of selected macroeconomic variables (World Bank for GDP and population; ILO for skilled and unskilled labor and IMF for capital).

Data on both the direct and indirect cost of trade are systematically catalogued in The World Bank's Doing Business Report. ${ }^{4}$ The detailed methodology for calculating country-specific and product-specific trade costs and their conversion into ad valorem or tariff equivalents is discussed in "Appendix 4."

\footnotetext{
${ }^{3}$ Available at http://www.macmap.org.

${ }^{4}$ Doing Business data are available online at http://www.doingbusiness.org.
} 


\section{Results}

This section reports the trade and welfare results for China and the TPP member countries in the two situations where

1. the USA continues to be part of the TPP

2. the USA is not a part of the TPP deal

\subsection{Trade}

China's trade with the TPP region is likely to fall after the trade liberalization in the TPP region irrespective of whether the USA is a part of TPP or not. Given the tariff commitments of the member countries by 2020, the total exports of China to the region will fall by $0.2 \%$ mainly due to fall in its exports to Malaysia, Japan, Brunei, Mexico, Canada and Peru. In the case of the deal without the USA, Vietnam too joins this group of countries where China's exports register a fall. The exports from China which are likely to register the maximum decrease in both the scenarios are: motor vehicles; meat and livestock and products thereof; processed food; leather and leather products; iron and steel and articles thereof; and machinery equipments. Exports of almost all products to Peru, Mexico and Malaysia decrease. In Japan and Canada, exports of meat, processed food and leather and leather products decline, while in Brunei along with processed food and leather products, the exports of machinery and motor vehicles also register decline.

Incidentally, most of the Chinese products, which show decline in exports to the TPP region, are also the products which register import increase within the TPP region and the new sources of imports are the other TPP countries. This clearly indicates that China's loss is TPP region's gain. While China's exports to TPP region fall by $0.2 \%$, the intraTPP export/import increases by $3 \%$, thus shifting many of the import sources (including China) from outside to inside TPP region. China's comparative advantage in several goods, particularly manufacturing, is common knowledge. Thus, replacing goods of Chinese origin by goods from other countries is clearly indicative of trade diversion that is likely to follow the tariff and non-tariff liberalization following the TPP. This is true even when the USA has withdrawn from the TPP agreement. In these current simulations where the member countries only partially liberalize the tariff barriers, China's export of leather and leather products falls in almost all TPP countries. But TPP region's total import of leather and leather products increases by $87 \%$. China is one of largest exporters of leather and leather products providing the good at way more competitive price than many of the countries within the TPP region. Thus, TPP is likely to result in substantial trade diversion whereby China may end up losing share of its export markets to the member countries. On the import front too, China's import from TPP countries declines by around $0.9 \%$ in both scenarios. The main sources from which the imports suffer are New Zealand, Vietnam, Singapore, Chile and the USA. The main products which register decline in imports into China are oilseeds, paper and paper products, nonmetallic minerals, machinery, electrical products and utility consumption.

Thus, in both the cases of TPP including the USA and excluding the USA, China's total trade with the TPP countries declines. It falls by $0.47 \%$ when the USA continues 
to be a member, while it falls by $0.49 \%$ if the USA withdraws. This is as per the scenario when the countries have implemented their tariff commitments of the year 2020 when the TPP is on its seventh year of implementation. As tariff liberalizations deepens further and heads toward completion by the year 2046, China's total exports to TPP region decline by $0.09 \%$, while imports still fall and register a total decline by $0.13 \%$. As the USA withdraws, China's exports after the phasing out of all of tariff by member countries continue to be $0.09 \%$ lesser but the import now falls marginally less $(0.12 \%)$. Thus, China's total trade with the region falls marginally lesser $(0.003 \%)$ when the USA is not a member of the TPP deal. Post-2020, China's exports to Japan would mainly fall. The other export markets which will suffer are Chile, Vietnam, Mexico, Canada and the USA. The exports of meat products, processed food and mineral fuels will take the hit. For China's imports from TPP region oilseeds, electrical products, textile and apparels, machinery, metals and wood and paper and products thereof will show further decline. China's imports from Australia, New Zealand and Brunei will suffer the most. Thus, the USA's withdrawal from the TPP does not have any major impact on China on the trade front.

If the tariff liberalization as per the two scenarios of 2020 and 2046 both with the USA and without the USA being a TPP member (as considered in the first two simulations) are further complemented by input augmenting technical change in the importing country and improvement in trade cost within the TPP region, China's trade with the region will decline further while the intra-TPP trade will register further growth. The input augmenting technical change scenario is simulated for the developing countries ${ }^{5}$ of the TPP region for the sectors in which the importing developing countries register increase in imports of inputs from the developed members of the region. This simulation represents a situation where production networks develop among the countries of the region where each country supplies inputs to the other depending on its comparative advantage and the importing country experiences a technological improvement due to such input imports or development of supply/production chains. However, import of input from any country may not result in technological improvement in the importing country. But it is more likely that import of inputs from the advanced developed countries may lead to technological advancement in developing countries. In fact, there are strong evidences of developing countries across the world relying largely on import of technologies from developed countries for driving their technological change. Thus, the present study considers the import of inputs by developing countries within the TPP from other developed members and considers a technological change to the extent of $10 \%$ in the sectors using these imported inputs.

The results of the simulation indicate that total export within the TPP region increases by a meager $0.003 \%$. And $0.49 \%$ of this increase is due to increase in input exports. China's exports do not suffer much due to this increased input trade. It only goes down by $.001 \%$ while China's import from the region comes down by $0.002 \%$, thus bringing down China's total trade with the region also by a meager $0.0015 \%$. Though the developing countries of the TPP region could have sourced large number of inputs from the

\footnotetext{
${ }^{5}$ As per International Monetary Fund classification, the 12 countries of the TPP region are classified into developed and developing countries as follows: developed-Australia, Canada, Japan, New Zealand, Singapore and the USA, and developing-Brunei Darussalam, Chile, Malaysia, Mexico, Peru and Vietnam.
} 
USA at concessional tariff rates had the USA been part of the deal, the latter's withdrawal from the deal does not alter the likely impact of an input augmenting technical change on the trade variables of the developing countries and hence on China. Possibly because a technical change to the extent of $10 \%$ hardly has any impact on the productivity and hence on the related macroeconomic and trade variables of the countries in the region.

However, a 5\% reduction in trade cost following improvement in cross-border efficiencies of the member countries post-TPP implementation (in its original form with the USA) increases the intra-TPP export/import by a larger $0.6 \%$. Brunei, Peru and Mexico experience the maximum increase in exports, and Brunei, Chile, New Zealand, Peru, Malaysia and Canada register the highest import growth. The products which record increase in exports/imports within the TPP region are apparel, mineral fuels, leather, textile, metal products, machinery, electrical equipment and livestock and meat products. China loses export of all these products in the TPP region. Its total trade with the region decreases by $0.02 \%$. In the absence of tariff concessions from the USA, the trade cost improvement increases intra-TPP trade by $0.8 \%$. If a member, the USA is likely to experience an increase of 0.6 percent in its exports to the region. So when it withdraws, some of this input demand is directed to the other TPP members and some of it is also reaches China. This is evident from the total exports figures of China which declines by $3.68 \%$ post-USA withdrawal as compared to $5.26 \%$ earlier. Most of this increased input demand facing China is for manufactured goods which now fall in the TPP region but by $2.48 \%$ as against $3.1 \%$ when the USA is a part of the TPP deal.

Thus, China's trade with TPP region is likely to suffer post-TPP implementation. This is true whether the TPP goes through with or without the USA. Whether it is only tariff liberalization by the countries or input augmenting technical change in the countries or trade cost reduction in the region, each of the scenarios is likely to increase the intraregional trade flow, while China's trade with the region continues to come down. Starting from around a $0.5 \%$ fall within the first 5 years, China's trade engagement with the region keeps falling consistently by another $0.10 \%$ by 2046 . There is an additional $0.001 \%$ fall if the TPP region experiences technical change due to increased production network. To this there is a further $0.02 \%$ decrease as the developing countries of the region work towards improving their trade costs. China's export to the region is likely to register a total fall of $0.3 \%$, while imports decrease by $1.05 \%$. The fall in the import figure is marginally less when the USA is not a part of the deal.

The welfare implications of this trade agreement to China and the negotiating countries are discussed in the following section.

\subsection{Welfare}

In GTAP modeling framework, welfare change estimates the change in utility due to distortions. It is the percentage change in per capita utility for a region due to a distortion such as a policy shock. The aggregate utility function for the region is specified over per capita private household consumption, per capita government spending and per capita savings. The welfare change is given in US \$million and is decomposed into: allocative efficiency effect, endowment effect and terms of trade effect. The welfare change accruing to China and the TPP region is due to the policy shock in the form of tariff 
liberalization between the TPP members, input augmenting technical change and the reduction in trade cost within the TPP region.

Intuitively, it is welfare improving to increase the level of a relatively taxed activity since this involves the reallocation of a commodity or endowment from a low value use to a relatively high social marginal usage. The same is true for endowments and for goods traded. Any good that yields trade tax to the economy benefits the country. The terms of trade for a region which is defined as the ratio of export price index of the region to its import price index contributes positively to the society if export prices post-simulation rises more than import prices. Similarly, endowment effect which captures changes in employment of factors of production that bring about a change in the productive capacity will show positive contribution if it adds to the productive capacity of the economy. Table 2 reports the welfare results.

The TPP agreement will fetch significant positive welfare gains for the entire TPP region to the tune of US $\$ 19675$ million by 2020 . This agreement when fully implemented along with input augmenting technical change and trade cost improvement in the developing countries of the region will take this welfare gain to stand at US $\$ 20,588$ million. As reported in Table 3, the developing countries of the region gain primarily on account of endowment gains. This is explained by the increased employment opportunities brought about by TPP agreement for the large pool of surplus labor force (unskilled) existing in these countries. Improved allocative efficiency will also fetch welfare gains for these countries. But they will lose out throughout on account of worsening terms of trade, excepting when the countries manage to lower their trade costs by improving their cross-border inefficiencies. The maximum welfare gain to the developing countries will be due to welfare increase enjoyed by Vietnam, Malaysia and Chile. The increased employment opportunities fetched by the trade agreement to the labor force in these economies explain the reason behind this welfare. While Malaysia's welfare is likely to remain more or less constant throughout the process of trade integration in the region, Chile and Vietnam will experience increased welfare as the trade liberalization deepens. Brunei too enjoys a stable welfare gain. But Mexico and Peru will start with welfare losses which will improve gradually and only slightly over time.

The developed countries of the region will gain due to positive terms of trade effect. The countries with the highest gains during the initial years of the TPP implementation are the USA, Japan, Australia and Singapore. These gains will tend to come down for the countries as tariff liberalization heads toward completion. Particularly, Japan will see a substantial fall in its welfare as its import prices are likely to rise over time. Australia is one country in this group which will enjoy rising welfare throughout due to huge terms of trade gains.

Thus, while the agreement is likely to result in lower export prices offered by developing countries to the developed countries, the former does not face equal reductions in import prices for the imports they fetch from the developed countries. Nevertheless, the endowment benefits and the resulting allocative efficiencies enable the developing countries to drive home substantial positive welfare gains in most of the scenarios. However, full implementation by 2046 will fetch reduced welfare to these developing members due to major worsening terms of trade. 


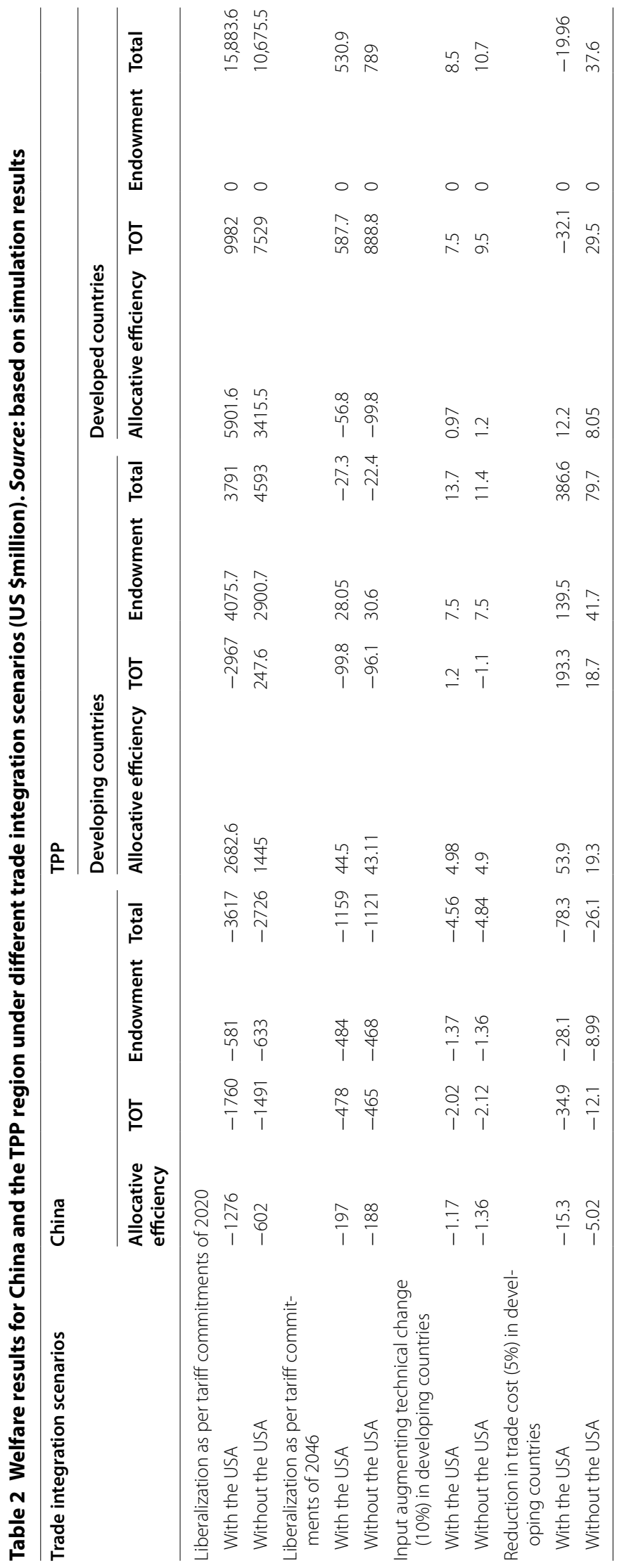


Table 3 Welfare results for TPP members under different trade integration scenarios (US \$million). Source: based on simulation results

\begin{tabular}{|c|c|c|c|c|c|c|c|c|}
\hline \multirow{2}{*}{$\begin{array}{l}\text { Trade integra- } \\
\text { tion scenarios } \\
\text { TPP countries }\end{array}$} & \multicolumn{4}{|c|}{$\begin{array}{l}\text { Liberalization as per tariff commitments } \\
\text { of } 2020\end{array}$} & \multicolumn{4}{|c|}{$\begin{array}{l}\text { Liberalization as per tariff commitments } \\
\text { of } 2046\end{array}$} \\
\hline & $\begin{array}{l}\text { Allocative } \\
\text { efficiency }\end{array}$ & TOT & Endowment & Total & $\begin{array}{l}\text { Allocative } \\
\text { efficiency }\end{array}$ & TOT & Endowment & Total \\
\hline \multicolumn{9}{|c|}{ Developing countries } \\
\hline With the USA & 2682.6 & -2967 & 4075.7 & 3791.3 & 44.5 & -99.8 & 28.05 & -27.2 \\
\hline Without USA & 1445 & 247.6 & 2901 & 4593 & 43.1 & -96.1 & 30.6 & -22.4 \\
\hline \multicolumn{9}{|l|}{$\begin{array}{l}\text { Brunei Darus- } \\
\text { salam }\end{array}$} \\
\hline With the USA & 49.5 & 0.023 & 13.1 & 63 & -0.28 & 3.2 & 0.06 & 3 \\
\hline Without USA & 44.6 & -2.2 & 11.9 & 54.3 & -0.28 & 3.1 & 0.06 & 2.9 \\
\hline \multicolumn{9}{|l|}{ Chile } \\
\hline With the USA & 51.2 & 379 & 157 & 587 & 9.3 & -2.3 & 4 & 11.01 \\
\hline Without USA & 75.2 & 613 & 286 & 974 & 9.3 & -2.8 & 4.1 & 10.6 \\
\hline \multicolumn{9}{|l|}{ Malaysia } \\
\hline With the USA & 609 & -1041 & 1267 & 835 & 0.50 & -48.6 & 12.2 & -35.9 \\
\hline Without USA & 518 & -876 & 1076 & 718 & 0.24 & -47.7 & 12.8 & -34.7 \\
\hline \multicolumn{9}{|l|}{ Mexico } \\
\hline With the USA & -308 & -5133 & -1038 & -6479 & 29.3 & -7.99 & -4.9 & 16.4 \\
\hline Without USA & 223 & -516 & 320 & 387 & 27.5 & -5.6 & -4.3 & 17.6 \\
\hline \multicolumn{9}{|l|}{ Peru } \\
\hline With the USA & -0.14 & -116 & 6.59 & -110 & -0.16 & 14.3 & 3.59 & 17.7 \\
\hline Without USA & 2.14 & -47.2 & 4.76 & -40.3 & -0.16 & 13.8 & 3.44 & 17.1 \\
\hline \multicolumn{9}{|l|}{ Vietnam } \\
\hline With the USA & 2281 & 2944 & 3670 & 8895 & 5.85 & -58.4 & 13.1 & -39.5 \\
\hline Without USA & 582 & 716 & 1202 & 2500 & 6.5 & -57 & 14.5 & -35.6 \\
\hline \multicolumn{9}{|c|}{ Developed countries } \\
\hline With the USA & 5901.6 & 9982 & 0 & $15,883.6$ & -56.8 & 587.7 & 0 & 530.9 \\
\hline Without USA & 3415.5 & 7529 & 0 & 10,675 & -99.7 & 889 & 0 & 789 \\
\hline \multicolumn{9}{|l|}{ Australia } \\
\hline With the USA & 494 & 759 & 0 & 1253 & 374 & 2468 & 0 & 2842 \\
\hline Without USA & 562 & 1310 & 0 & 1872 & 359 & 2380 & 0 & 2739 \\
\hline \multicolumn{9}{|l|}{ Canada } \\
\hline With the USA & 1234 & -198 & 0 & 1036 & 4.61 & -25.9 & 0 & -21.3 \\
\hline Without USA & 659 & 2135 & 0 & 2794 & 5.9 & -11.8 & 0 & -5.9 \\
\hline \multicolumn{9}{|l|}{ Japan } \\
\hline With the USA & 4206 & 856 & 0 & 5062 & -460 & -1397 & 0 & -1857 \\
\hline Without USA & 2046 & 1958 & 0 & 4004 & -461 & -1375 & 0 & -1836 \\
\hline \multicolumn{9}{|l|}{ New Zealand } \\
\hline With the USA & 87.3 & 590 & 0 & 677 & -1.6 & -74.4 & 0 & -76 \\
\hline Without USA & 96.3 & 676 & 0 & 772 & -1.3 & -68.2 & 0 & -69.5 \\
\hline \multicolumn{9}{|l|}{ Singapore } \\
\hline With the USA & 51.3 & 1198 & 0 & 1249 & -2.45 & -37 & 0 & -39.5 \\
\hline Without USA & 52.2 & 1180 & 0 & 1232 & -2.4 & -36 & 0 & -38.6 \\
\hline \multicolumn{9}{|l|}{ USA } \\
\hline With the USA & -171 & 6777 & 0 & 6606 & 28.6 & -346 & 0 & -317.4 \\
\hline Without USA & - & - & - & - & - & - & - & - \\
\hline
\end{tabular}


Table 3 continued

\begin{tabular}{|c|c|c|c|c|c|c|c|c|}
\hline \multirow{2}{*}{$\begin{array}{l}\text { Trade integra- } \\
\text { tion scenarios } \\
\text { TPP countries }\end{array}$} & \multicolumn{4}{|c|}{$\begin{array}{l}\text { Input augmenting technical change (10\%) } \\
\text { in developing countries }\end{array}$} & \multicolumn{4}{|c|}{$\begin{array}{l}\text { Reduction in trade cost (5\%) in developing } \\
\text { countries }\end{array}$} \\
\hline & $\begin{array}{l}\text { Allocative } \\
\text { efficiency }\end{array}$ & TOT & Endowment & Total & $\begin{array}{l}\text { Allocative } \\
\text { efficiency }\end{array}$ & TOT & Endowment & Total \\
\hline \multicolumn{9}{|c|}{ Developing countries } \\
\hline With the USA & 4.98 & 1.2 & 7.53 & 13.7 & 53.9 & 193.3 & 139.5 & 386.6 \\
\hline Without USA & 4.9 & -1.1 & 7.6 & 11.4 & 19.3 & 18.7 & 43.01 & 81.04 \\
\hline \multicolumn{9}{|l|}{$\begin{array}{l}\text { Brunei Darus- } \\
\text { salam }\end{array}$} \\
\hline With the USA & 0.083 & 0.02 & 0.02 & 0.126 & 0.34 & 1.83 & 0.16 & 2.33 \\
\hline Without USA & 0.014 & 0.03 & 0.02 & 0.19 & 0.29 & 1.86 & 0.14 & 2.3 \\
\hline \multicolumn{9}{|l|}{ Chile } \\
\hline With the USA & 0.19 & -0.11 & 0.15 & 0.23 & 3.5 & 10.9 & 7.12 & 21.5 \\
\hline Without USA & 0.18 & -0.12 & 0.4 & 0.2 & 2.4 & 9.2 & 4.53 & 16.1 \\
\hline \multicolumn{9}{|l|}{ Malaysia } \\
\hline With the USA & 2.78 & -0.22 & 4.06 & 6.6 & 4.58 & 13.6 & 11.6 & 29.8 \\
\hline Without USA & 3.02 & -0.13 & 4.3 & 7.2 & 3.6 & 10.7 & 8.8 & 23 \\
\hline \multicolumn{9}{|l|}{ Mexico } \\
\hline With the USA & 0.007 & -0.07 & .096 & 0.03 & 28.6 & 138 & 91.9 & 258.5 \\
\hline Without USA & 0.001 & 0.05 & 0.13 & 0.18 & 5.9 & 13.9 & 11.2 & 31 \\
\hline \multicolumn{9}{|l|}{ Peru } \\
\hline With the USA & 0.032 & -0.03 & 0.38 & 1.37 & 0.87 & 3.53 & 5.5 & 9.87 \\
\hline Without USA & 0.014 & 0.012 & 0.15 & 0.18 & 0.56 & 3.19 & 3.2 & 6.9 \\
\hline \multicolumn{9}{|l|}{ Vietnam } \\
\hline With the USA & 1.89 & 1.61 & 2.83 & 6.3 & 16 & 25.4 & 23.2 & 64.6 \\
\hline Without USA & 1.82 & 1.55 & 2.71 & 6.1 & 9.3 & 14.6 & 13.9 & 37.8 \\
\hline
\end{tabular}

The USA has significant welfare gain (US $\$ 6606$ millions) when tariff liberalization as per the initial commitments of 2020 is done. Thus, the withdrawal of the country from the TPP region lowers the total welfare accruing to the region. However, not all the gains on account of the USA are lost as some of the gains get redistributed in favor of the other countries of the region. The total welfare of the developing countries in the region is likely to go up from US \$3791 million to US \$4593 million (Table 3) after the USA withdrawal. The countries which are likely to gain are Chile, Peru and most importantly Mexico. Improved allocative efficiency and improved terms of trade are the factors which drive this welfare gain. The developed countries as a group now will gain less, but some individual countries like Australia, New Zealand and Canada will witness an improvement in their welfare positions. This is primarily owing to improved terms of trade. However, the situation in 2046 is just opposite with the developed countries (mainly Canada and to some extent New Zealand) witnessing better welfare positions than they do with the USA being a member of the deal. This too is owing to improvement in their terms of trade. As the countries of the region integrate further as is captured by the technical change and trade cost improvement scenarios, the developing countries welfare does not improve any further when the USA is not a TPP member. The technical change hardly fetches any welfare improvement except that some countries like Brunei and Malaysia 
which experience marginal improvement due to better allocative efficiency and endowment gains. The trade cost improvement now actually lowers substantially the welfare to the developing countries (from US $\$ 387$ million to US $\$ 81$ million). This is due to major loss in all of allocative efficiency, terms of trade and endowment gains. Thus, better production networks in the region and improvement in cross-border efficiencies are going to pay off the developing countries provided the USA continues to be part of the TPP deal. Thus, with or without the USA, both the developed and developing countries are likely to gain from this deal. Thus, if the remaining countries choose to go ahead with the deal, they will definitely drive home positive though lesser gains.

As for China, the country has huge welfare losses due to all of allocative inefficiencies, worsening terms of trade and endowment effect if TPP goes through in its initial form with the USA a member country. Thus, due to its changed trade pattern with the TPP region China not only reallocates the commodities and factor employments from high value use to a relatively low social marginal usage, but also faces import prices from TPP region which is way higher than the export prices it offers to the countries of the region. Moreover, China's welfare loss intensifies as the tariff liberalization and integration among the TPP countries deepen. As the USA withdraws, China's welfare position improves but continues to be negative on all on three welfare accounts. As the USA moves out of the deal, the allocative efficiency and endowment gains both improve for China.

Thus, the TPP agreement is likely to displace some of the trade that is currently taking place between China and the TPP region. Though this displacement is not of a large magnitude, it is likely to result in substantial trade diversion. Most importantly, it will result in large welfare losses for China whether the USA stays a member to the deal or not.

\section{Conclusion}

TPP agreement of October 2015, the largest regional trade accord in history, if approved, was likely to set new terms of trade, business and investment among the 12 Pacific Rim nations - a group with an annual gross domestic product worth nearly US \$28 trillion and accounting for one-third of total world trade. Thus, in terms of economic footprints TPP was supposed to be way larger than any trade agreement that the world would have seen it recent times. But before it could be approved, USA, the biggest member, withdrew from the deal citing reasons of threat to national sovereignty and domestic jobs. This was after the shift of political power in the country in November 2016. At present, the TPP is the focus of much debate and discussion regarding whether it should go through without the USA or should the USA be convinced to relook at the prospects of joining back. But, whether with or without the USA, the important point to note about the TPP deal is that it does not include China-the largest merchandise trader of the world.

China has not been ready to accept the huge array of TPP obligations related to transparency and discipline regarding government intervention in the market. Besides, TPP obligations also posed great challenges to the country in form of labor rights, freedom of data flows and intellectual property. Thus, China, which had $49 \%$ of its total goods trade with the original 12 TPP countries, stayed out of this trade agreement for the time being 
to assess the likely impact of the deal on it. But with the USA wanting to stay out of TPP now, China may definitely want to relook at the alternatives of staying out of the TPP or joining it. This is because of the many countries of the TPP region where China's trade has been concentrated and the USA has been the most important one.

Against this backdrop, the present paper seeks to analyze the impact of the TPP agreement, both with and without the USA, on China. Using the computable general equilibrium framework of the GTAP database, it does a number of simulations by calibrating various trade integration scenarios between the TTP countries and observes, the likely impact of these liberalizations scenarios on China's trade and welfare position.

The results of the study point out that the TPP agreement is likely to displace some of China's current trade with the TPP region. Starting from simply liberalizing tariff to deeper trade integration in the form of developing production networks or improving trade costs, each of the scenarios will increase intra-TPP trade and lower China's trade with the region. The decrease is likely to range from $0.5 \%$ in the initial years to $0.6 \%$ after the entire phasing out period. China's export to the region will fall around $0.3 \%$, and imports from the region are likely to decrease by $1.05 \%$. Though the magnitude of this decline may not be large, it is likely to result in much trade diversion. Most importantly, it will result in large welfare losses for China.

China's welfare loss will range between US \$2682 million to US \$2784 million. Increased allocative inefficiencies, worsening terms of trade and loss of employment opportunities are coupled together to explain this loss of welfare. Thus, China's changed trade pattern with the TPP region will relocate much of its commodity productions and factor employments from high value use to a relatively low social marginal usage. The stiff competition that the country is likely to face in the TPP region will force it to lower much of its export prices to the region, thereby resulting in worsening its terms of trade with this group of countries.

The negative impact on China's trade and welfare does alter but marginally after the withdrawal of the USA. As the USA moves out, China's exports continue to fall as much as it does with USA being part of the deal but imports now fall slightly lesser (by $0.003 \%$ ). Thus, impact of TPP on China's trade front is by and large the same with or without the USA. On the welfare front too, China's positions improve in the different liberalization scenarios, but the welfare figures continue to stay in the negative zone. The slight welfare improvements that happen are due to betterment in terms of allocative efficiency and endowment gains.

However, China has currently taken a "wait-and-see" approach toward TPP. But had the agreement got implemented in its original form with the USA a member of the deal, it would have definitely meant greater losses for China on both its trade and welfare front. But now with the USA likely to be out of the deal China might want to rethink and relook at the challenges of TPP obligations vis à vis the opportunities that the agreement is likely to fetch for it. Particularly, given its "living agreement" status, if the TPP expands to other important Asian trading partners, China would definitely have to reconsider its stance related to TPP membership. 


\section{Additional file}

Additional file 1. Supporting files for GTAP framework.

\section{Authors' contributions}

Both authors have contributed to conception and design, acquisition of data, and its analysis and interpretation. They have also been involved in drafting the manuscript and revising it critically for important intellectual content. They have also given final approval of the version to be published. Both authors read and approved the final manuscript.

\section{Author details}

${ }^{1}$ School of Business Management, Narsee Monjee Institute of Management Studies, V. L. Mehta Road, Mumbai 400056, India. ${ }^{2}$ Gokhale Institute of Politics and Economics, Pune 4110004 , India. ${ }^{3}$ Department of Natural Resource Sciences, Agricultural Economics Program, McGill University, Macdonald Campus, 21,111 Lakeshore Road, Ste Anne de Bellevue, Montreal, QC H9X3V9, Canada. ${ }^{4}$ Academy of Mathematics and Systems Science, Chinese Academy of Science, 55 Zhongguancun Dong Lu, Haidian District, Beijing 100190, P.R. China.

\section{Acknowledgements}

Not applicable.

Competing interests

The authors declare that they have no competing interests.

Availability of data and materials

The dataset supporting the conclusions of this article is available in and bought from the GTAP database version 9.

Consent for publication

Not applicable.

Ethics approval and consent to participate

Not applicable.

Funding

Not applicable.

\section{Appendix 1: GTAP-A CGE modeling framework}

A complete analysis of trade and trade-related issues requires an analytical framework which takes into account a holistic view of the economies across the world. This is because there are not only inter-linkages present between various sectors of an economy but sectors in an economy are also linked to rest of the world by the way of exports, imports of final products, intermediate goods, capital goods and so on. Thus, linkages are present at the national, regional as also at the global level both in product and in the input markets. The present study makes an attempt to integrate these linkages considering the Global Trade Analysis Project (GTAP) as the analytical tool. The global computable general equilibrium (CGE) modeling framework of the GTAP is one of the best possible ways to analyze ex ante the economic consequences and trade implications of multilateral and bilateral trade agreements.

Global Trade analysis Project (GTAP), originally formulated by Hertel (1997), is a multi-regional applied general equilibrium model which captures the economic activity across the world in 57 different sectors of 140 regions (version 9 of the GTAP database). The system of equations underlying the GTAP model consists of two different types of equations. One set comprises of the accounting relationships which balances the receipts and expenditures of every agent in the economy. The other set comprises of the behavioral equations which is based on microeconomic theory and describes the behavior of optimizing agents in the economy like demand function and supply function.

To understand the model and how it applies in context of the present study, we look at the GTAP model under the following subheadings. 


\section{The framework}

The GTAP modeling framework comprises of the following economic agents (Fig. 5):

- Household

- Government

- Producer

\section{Household: its role}

- Earns income which is spent on purchase and savings

- Spends on goods and services (private household expenditure, PRIVEXP) which results in demand for the goods and services sold by domestic producers (value of domestic private household purchases, VDPA) and also spends on imported goods (VIPA)

- Saves

- Sales endowments or factor services to firms and earns value of output they produce (VOA). This is the source of their income

- Pays taxes to and receives subsidies from government. The net taxes paid are denoted as taxes

\section{Government: its role}

- Earns income by way of taxes on consumption and production

- Spends on goods and services (government expenditure, GOVEXP) which results in demand for the goods and services sold by firms (value of domestic government purchases, VDGA)) and also spends on imported goods (VIGA)

- Gives subsidies

\section{Regional household}

Private household plus government make the regional household. Thus, regional household is an entity that owns the factors of production and can tax other entities (firms, activities) and decides on the consumption expenditure. It allocates expenditures on private consumption (PRIVEXP), public consumption (GOVEXP) and savings (SAVE). The later go to the global banks and the global bank finances investment (NETINV).

\section{Producer: its role}

- Receives payments by selling final goods and services to private domestic households (VDPA); to government (VDGA); intermediate goods to domestic producers (VDFA); and intermediate and final goods to foreign producers (VXMD)

- Use this revenue earned to hire factors of production (VOA) and for buying domestic intermediate inputs (VDPA) and foreign intermediate inputs (VIFA)

- Pay taxes and receive subsidies. The net taxes paid are denoted as taxes

Thus, the GTAP model describes the world (global) economy consisting of regional economies, each of which consists of many producers and is governed by a regional household taking decisions about the private and public consumption and savings. The production structure/technology in the economy is represented by a CES production 
function and preferences of household by Cobb-Douglas production function. Each of these economies has the same theoretical structure, but they differ in size and parameters. The standard assumptions of the GTAP model are:

- Perfect competition

- Constant returns to scale

- Static model, no inter-temporal choice, no dynamics

- International trade in differentiated products (Armington assumption)

\section{Welfare in standard GTAP Model and in present study}

Welfare change in the standard GTAP model estimates the change in utility in the region due to distortions such as a policy shock. The aggregate utility function for the region is specified over per capita private household consumption, per capita government spending and per capita savings. The welfare change is given in US \$million and is decomposed into: allocative efficiency effect, endowment effect and terms of trade effect. Normally, welfare improvement associated with a policy shock in the form of trade liberalization may be due to-more favorable terms of trade, improved allocation of existing resources, additional resources, improvement in technology and improvement in employment of factor resources. Accordingly, welfare gains in GTAP are decomposed into:

- Allocative efficiency gains-these gains result when resources are reallocated into areas of more efficient production

- Terms of trade effects-these gains reflect movement in terms of trade due to changes in regional export prices and regional import prices

- Endowment effect-these gains result when factors of production (land, natural resources, labor, capital) are reallocated into areas of more efficient production

The welfare changes accruing to the economies in the present study are due to policy shocks involving:

- Tariff liberalization among the countries of the TPP region

- Input augmenting technical change in the TPP region

- Improvement in trade cost in the region

\section{Closures and shocks in standard GTAP Model and in the present study}

Simulations in GTAP model as in most CGE models involve examining comparative static results, i.e., it considers the impact that changes in exogenous parameters have on allocation of goods among consumers and resources among productive activities and also the consequences for economic efficiency. These changes in exogenous parameters are referred to as shocks. Thus, the exogenous variables of the GTAP model need to be selected at the outset based on the shocks one would want any economy/economies or region to experience. This set of exogenous variables selected at the outset represents the closure of the specific model. Once the closure is decided and the shocks are applied to the chosen exogenous variable/variables, the model works to give results which compare alternative equilibrium states-one before the shock and one after the shock. The results 


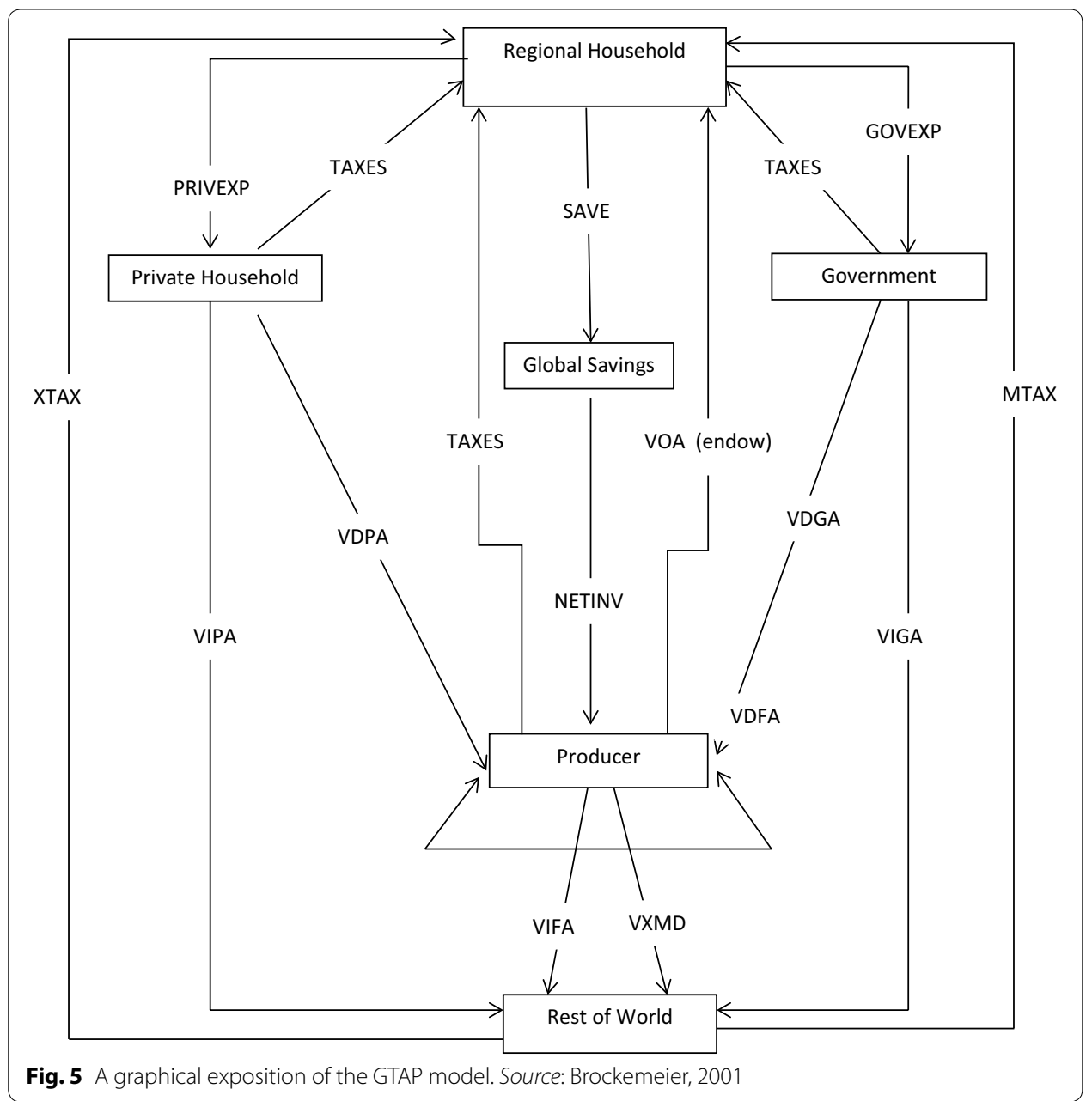

of the simulations (which involve different shocks) are interpreted as representing how the economic system under study would look if the shock (usually a policy intervention) takes place in the base year.

In the present study, the simulations done involve tariff reduction between the countries of the TPP region, technological changes and improvement in trade costs. Thus, for the purpose of this study, import taxes, technology of production sectors and trade costs associated with the import of different goods had to be exogenous. All these parameters are already in the set of exogenous variables in the standard GTAP model. Hence, no changes to the set of exogenous variables were required to be done for the present study. However, a standard GTAP closure is defined so as to consider full employment. This is a neoclassical approach whereby the endowments of the productive factors are fixed allowing the market prices to adjust so as to maintain full employment. But full employment is far from true in the real world, particularly for unskilled labor force and 
that too for developing countries. Thus, the simulations conducted in this paper replace this assumption of full employment with existence of unemployment for unskilled labor force in all the countries. This is done by fixing the real wages of unskilled labor rather than their endowment in these countries. Thus, market prices of unskilled labor no longer adjust to ensure full employment, but instead capture the unemployment with respect to unskilled labor in each of the economies. (Additional file 1)

\section{Appendix 2: China's top export markets and import sources in the TPP region}

See Tables 4 and 5.

Table 4 China's top exports to its top export markets in TPP region (2015)

\begin{tabular}{|c|c|c|c|}
\hline Country & Top exports of China & $\begin{array}{l}\text { Percent of total } \\
\text { exports to the } \\
\text { country }\end{array}$ & $\begin{array}{l}\text { Average ad valorem } \\
\text { tariff applied } \\
\text { by importing country }\end{array}$ \\
\hline \multirow[t]{5}{*}{ Australia } & $\begin{array}{l}\text { Machinery, mechanical appliances, nuclear reactors, } \\
\text { boilers }\end{array}$ & 18.7 & 2.5 \\
\hline & Electrical machinery and equipment & 15.3 & 2.1 \\
\hline & $\begin{array}{l}\text { Furniture, bedding, mattresses, cushions and similar } \\
\text { stuffed furnishings }\end{array}$ & 7.6 & 4.6 \\
\hline & $\begin{array}{l}\text { Articles of apparel and clothing accessories, knitted } \\
\text { or crocheted }\end{array}$ & 5.4 & 4.8 \\
\hline & Articles of iron or steel & 4.5 & 4.3 \\
\hline \multirow[t]{5}{*}{ Canada } & Electrical machinery and equipment & 16.5 & 0.6 \\
\hline & $\begin{array}{l}\text { Machinery, mechanical appliances, nuclear reactors, } \\
\text { boilers }\end{array}$ & 14.5 & 0.2 \\
\hline & $\begin{array}{l}\text { Furniture, bedding, mattresses, cushions and similar } \\
\text { stuffed furnishings }\end{array}$ & 9.1 & 5.1 \\
\hline & Articles of iron or steel & 5.3 & 1.2 \\
\hline & $\begin{array}{l}\text { Articles of apparel and clothing accessories, knitted } \\
\text { or crocheted }\end{array}$ & 4.7 & 17.5 \\
\hline \multirow[t]{5}{*}{ Japan } & Electrical machinery and equipment & 24.9 & 0 \\
\hline & $\begin{array}{l}\text { Machinery, mechanical appliances, nuclear reactors, } \\
\text { boilers }\end{array}$ & 16 & 0 \\
\hline & $\begin{array}{l}\text { Articles of apparel and clothing accessories, knitted } \\
\text { or crocheted }\end{array}$ & 6.5 & 9.9 \\
\hline & $\begin{array}{l}\text { Articles of apparel and clothing accessories, not knit- } \\
\text { ted or crocheted }\end{array}$ & 5.7 & 8.9 \\
\hline & $\begin{array}{l}\text { Optical, photographic, cinematographic, measuring, } \\
\text { checking, precision, medical or surgical equipment }\end{array}$ & 3.6 & 0 \\
\hline \multirow[t]{5}{*}{ Malaysia } & Electrical machinery and equipment & 21 & 0.1 \\
\hline & $\begin{array}{l}\text { Machinery, mechanical appliances, nuclear reactors, } \\
\text { boilers }\end{array}$ & 11 & 0.9 \\
\hline & $\begin{array}{l}\text { Furniture, bedding, mattresses, cushions and similar } \\
\text { stuffed furnishings }\end{array}$ & 5.8 & 0 \\
\hline & $\begin{array}{l}\text { Optical, photographic, cinematographic, measuring, } \\
\text { checking, precision, medical or surgical equipment }\end{array}$ & 4.3 & 0 \\
\hline & Plastics and articles thereof & 3.8 & 1.3 \\
\hline \multirow[t]{4}{*}{ Mexico } & Electrical machinery and equipment & 24.7 & 2 \\
\hline & $\begin{array}{l}\text { Machinery, mechanical appliances, nuclear reactors, } \\
\text { boilers }\end{array}$ & 19.9 & 1.5 \\
\hline & $\begin{array}{l}\text { Optical, photographic, cinematographic, measuring, } \\
\text { checking, precision, medical or surgical equipment }\end{array}$ & 9.5 & 2.5 \\
\hline & $\begin{array}{l}\text { Vehicles other than railway or tramway rolling stock, } \\
\text { and parts and accessories thereof }\end{array}$ & 5.4 & 20.2 \\
\hline
\end{tabular}


Table 4 continued

\begin{tabular}{|c|c|c|c|}
\hline Country & Top exports of China & $\begin{array}{l}\text { Percent of total } \\
\text { exports to the } \\
\text { country }\end{array}$ & $\begin{array}{l}\text { Average ad valorem } \\
\text { tariff applied } \\
\text { by importing country }\end{array}$ \\
\hline & $\begin{array}{l}\text { Furniture, bedding, mattresses, cushions and similar } \\
\text { stuffed furnishings }\end{array}$ & 3 & 9.1 \\
\hline \multirow[t]{5}{*}{ Singapore } & Electrical machinery and equipment & 27.9 & 0 \\
\hline & $\begin{array}{l}\text { Machinery, mechanical appliances, nuclear reactors, } \\
\text { boilers }\end{array}$ & 15 & 0 \\
\hline & Ships, boats and floating structures & 10.4 & 0 \\
\hline & $\begin{array}{l}\text { Mineral fuels, mineral oils and products of their } \\
\text { distillation }\end{array}$ & 7.3 & 0 \\
\hline & $\begin{array}{l}\text { Furniture, bedding, mattresses, cushions and similar } \\
\text { stuffed furnishings }\end{array}$ & 6 & 0 \\
\hline \multirow[t]{5}{*}{ USA } & Electrical machinery and equipment & 23 & 0.7 \\
\hline & $\begin{array}{l}\text { Machinery, mechanical appliances, nuclear reactors, } \\
\text { boilers }\end{array}$ & 20.5 & 0.6 \\
\hline & $\begin{array}{l}\text { Furniture, bedding, mattresses, cushions and similar } \\
\text { stuffed furnishings }\end{array}$ & 7 & 1.1 \\
\hline & Articles of apparel and clothing accessories & 4.3 & 14.4 \\
\hline & Toys, games and sports requisites & 3.7 & 0.7 \\
\hline \multirow[t]{5}{*}{ Vietnam } & Electrical machinery and equipment & 19 & 0.4 \\
\hline & $\begin{array}{l}\text { Machinery, mechanical appliances, nuclear reactors, } \\
\text { boilers }\end{array}$ & 10.3 & 1 \\
\hline & Iron and steel & 6.3 & 2.1 \\
\hline & Man-made staple fibers & 4 & 4.5 \\
\hline & Aluminum and articles thereof & 4 & 0.3 \\
\hline
\end{tabular}

Table 5 China's top imports from its top import sources in TPP region (2015). Source: Trade Map (available at http://www.trademap.org)

\begin{tabular}{|c|c|c|c|}
\hline Country & Top Imports of China & $\begin{array}{l}\text { Percent } \\
\text { of total } \\
\text { exports }\end{array}$ & $\begin{array}{l}\text { Average ad valorem } \\
\text { tariff applied } \\
\text { by China }\end{array}$ \\
\hline \multirow[t]{4}{*}{ Australia } & Ores, slag and ash & 55.7 & 0 \\
\hline & Mineral fuels, mineral oils and products of their distillation & 3.3 & 0.5 \\
\hline & Copper and articles thereof & 2.9 & 51.3 \\
\hline & Cereals & 2 & 20.3 \\
\hline \multirow[t]{5}{*}{ Canada } & Pulp of wood or of other fibrous cellulosic material & 11.4 & 0 \\
\hline & Oil seeds and oleaginous fruits & 9.4 & 3 \\
\hline & Ores, slag and ash & 5.8 & 0 \\
\hline & Wood and articles of wood; wood charcoal & 5.7 & 3 \\
\hline & Electrical machinery and equipment & 2.8 & 5 \\
\hline \multirow[t]{5}{*}{ Japan } & Electrical machinery and equipment & 27.1 & 5.1 \\
\hline & Machinery, mechanical appliances, nuclear reactors, boilers & 18.4 & 5.4 \\
\hline & $\begin{array}{l}\text { Optical, photographic, cinematographic, medical or surgical } \\
\text { equipment }\end{array}$ & 10 & 5.8 \\
\hline & $\begin{array}{l}\text { Vehicles other than railway or tramway rolling stock, and parts } \\
\text { and accessories thereof }\end{array}$ & 8.7 & 19.5 \\
\hline & Plastics and articles thereof & 6 & 7.5 \\
\hline \multirow[t]{4}{*}{ Malaysia } & Electrical machinery and equipment & 61 & 1 \\
\hline & Mineral fuels, mineral oils and products of their distillation & 10.8 & 0.3 \\
\hline & Machinery, mechanical appliances, nuclear reactors, boilers & 6.2 & 0.4 \\
\hline & Animal or vegetable fats and oils & 3.3 & 4.8 \\
\hline
\end{tabular}


Table 5 continued

\begin{tabular}{|c|c|c|c|}
\hline Country & Top Imports of China & $\begin{array}{l}\text { Percent } \\
\text { of total } \\
\text { exports }\end{array}$ & $\begin{array}{l}\text { Average ad valorem } \\
\text { tariff applied } \\
\text { by China }\end{array}$ \\
\hline & Rubber and articles thereof & 2.7 & 2.7 \\
\hline \multirow[t]{5}{*}{ Singapore } & Electrical machinery and equipment & 32 & 1 \\
\hline & Machinery, mechanical appliances, nuclear reactors, boilers & 14.5 & 0.4 \\
\hline & Plastics and articles thereof & 13 & 0.8 \\
\hline & Mineral fuels, mineral oils and products of their distillation & 10.5 & 0.3 \\
\hline & Organic chemicals & 8 & 0.4 \\
\hline \multirow[t]{5}{*}{ USA } & Electrical machinery and equipment & 13 & 5.1 \\
\hline & Aircraft, spacecraft, and parts thereof & 11.7 & 2.2 \\
\hline & Machinery, mechanical appliances, nuclear reactors, boilers & 10.5 & 5.4 \\
\hline & Vehicles other than railway or tramway rolling stock & 8.8 & 19.5 \\
\hline & Oil seeds and oleaginous fruits & 8.6 & 2.9 \\
\hline \multirow[t]{6}{*}{ Vietnam } & Electrical machinery and equipment & 45.8 & 1 \\
\hline & Cotton & 5.8 & 3.4 \\
\hline & Machinery, mechanical appliances, nuclear reactors, boilers & 5.3 & \\
\hline & Mineral fuels, mineral oils and products of their distillation & 4.4 & 0.4 \\
\hline & Footwear, gaiters and the like, parts of such articles & 4 & 0.3 \\
\hline & & 4 & 0 \\
\hline
\end{tabular}

\section{Appendix 3: Regional aggregation}

The 140 regions in GTAP database version 9 are aggregated into 14 regions for the purpose of this study. They are China, Australia, Brunei Darussalam, Canada, Chile, Japan, Malaysia, Mexico, New Zealand, Peru, Singapore, the USA, Vietnam and the Rest of the world.

\section{Sectors undertaken in simulations (sectoral aggregation)}

The 57 sectors of the GTAP model have been aggregated into 22 sectors in this study. Considering the importance of manufacturing products for China, these sectors are considered as much disaggregated as possible. The sectors are namely grains and crops, oilseeds, meat and livestock and its products, fishing and forestry, mineral fuels, processed food, textiles, wearing apparels, leather and leather products, wood and wood products, paper and paper products, chemical, rubber and plastic, nonmetallic mineral products, ferrous metals, other metals, metal products, machinery equipment, electrical equipment, motor vehicles, other manufacturing, utilities and services.

\section{Appendix 4: Relevant data and methodology for handling trade cost}

Cross-border inefficiencies, or trade transaction costs (TTCs), are of two types:

- Direct costs - these include charges such as customs fees, port handling charges and informal payments. These are directly assessed on each transaction.

- Indirect costs-these are costs that refer to the cost of time in trade. For an exporter, these include the time required to complete all pre-shipment requirements and also the loading of cargo. For an importer, it is the time taken to take possession of the shipments once the ship has arrived at the port 
Data on both the direct and indirect costs of trade are systematically catalogued in The World Bank's Doing Business Report. For the purpose of this study, data on trade costs have been collected for all of China and the 12 member countries of the TPP region. And then a $10 \%$ reduction is applied to the trade costs for goods reaching and leaving the developing countries of the TPP region. To use a CGE modeling framework, the time costs of trade which are typically measured and recorded in days have to be converted into cost units in dollars. To do this, the study uses data by Hummels et al. (2007) on ad valorem tariff equivalents for the cost of 1 day in trade for the 12 TPP countries and the China. Following Hummels et al's (2007) methodology, the tariff equivalents of trade delays considered in this study counted time in three stages: inland transport, customs processing and port handling. These values are then trade weighted using the bilateral trade data between the TPP countries as reported in GTAP database 9 (as updated earlier as part of the study). The bilateral trade flow corresponds to the direction of the trade, i.e., export time is export weighted and import time is import weighted. Tariff equivalents of time are created for all the 22 products and for the TPP countries and China.

The reduction in trade cost is implemented as in Hertel et al. (2003). In this approach, the product- and region-specific Armington demand function is shifted by the ad valorem tariff equivalent of the reduction in the number of days to cross-borders. It can be shown that this shifting parameter has the desired effect of reducing the market price of imported goods by the percentage shift in the demand curve and with a corresponding change in the quantity demanded. As the reduction in market price is simulated as a technical shift, no rebalancing of the database is required. Following the standard analysis of Armington functions, changing import demand and supply is a function of change in relative prices, demand and substitution elasticities, supply constraints and trade shares (Minor and Tsigas 2008).

\section{Publisher's Note}

Springer Nature remains neutral with regard to jurisdictional claims in published maps and institutional affiliations

Received: 7 April 2017 Accepted: 23 July 2017

Published online: 13 September 2017

\section{References}

Burfisher ME (2012) Introduction to computable general equilibrium models. Cambridge University Press, New York Ghemawat P (2016) If Trump abandons the TPP, China will be the Biggest Winner. Harvard Business Review, December 2016. https://hbr.org/2016/12/if-trump-abandons-the-tpp-china-will-be-the-biggest-winner. Accessed 12 Dec 2016 Gilbert JP (2001) Appendix: GTAP model analysis: simulating the effect of a Korea—US FTA using computable general equilibrium techniques in free trade between Korea and the United States? Policy analyses in international economics 62. Institute for International Economics, Washington, D.C.

Global Economic Prospects (2016) Potential macroeconomic implications of the Trans-Pacific Partnership. World Bank Group. http://elibrary.worldbank.org/doi/abs/. Accessed 15 Nov 2016

Global Trade Analysis Project, Purdue University (2016) GTAP databases 9. https://www.gtap.agecon.purdue.edu. Accessed 10 Nov 2016

Hertel WH, Walmsley T, Itakura K (2003) Dynamic effects of the 'new age' free trade agreement between Japan and Singapore. GTAP Technical Paper 823. https://www.gtap.agecon.purdue.edu/resources/download/548.pdf. Accessed 5 Sept 2014

Hummels D, Minor P, Reisman M, Endean E (2007) Calculating tariff equivalents for time in trade. Review paper of United States Agency for International Development. http://www.nathaninc.com/sites/default/files/. Accessed 5 Sept 2014

International Labour Organization (2015) World employment social outlook. Trends 2015. http://www.lo.org/wcmsp5/. Accessed 20 Dec 2015 
International Monetary Fund, World Economic Outlook. Uneven growth-short and long term factors. http://www.imf. org/external/pubs/ft/weo/2015/01. Accessed 2 Dec 2014

Llosa AV (2016) China's gain? The collapse of the TPP could be bad for everyone. http://www.cnbc.com/2016/11/16/ chinas-gain-the-collapse-of-the-tpp-could-be-bad-for-everyone. Accessed 23 Dec 2016

Minor P, Tsigas M (2008) Impacts of better facilitation in developing countries. GTAP Technical Paper 4036. https://www. gtap.agecon.purdue.edu/. Accessed 5 Sept 2014

Naughton B, Krobber AR, Jonquieres GD, Webster G (2005) What will the TPP mean for China. http://foreignpolicy. com/2015/10/07/china-tpp-trans-pacific-partnership-obama-us-trade-xi/. Accessed 20 March 2016

Petri PA, Plummer MG (2016) Economic effects of TPP, new estimates. In: Schott Jeffrey J, Kotschwar Barbara, Muir Julia (eds) Policy analyses in international economics. Peterson Institute of International Economics, Washington, D.C.

Petri PA, Plummer MG, Zhai F (2012) The Trans-Pacific Partnership and Asia-pacific integration: a quantitative assessment, vol 98. Peterson Institute, Washington, D.C.

Rosenfeld Everett (2016) CNBC Report; China's gain? The collapse of the TPP could be bad for everyone. http://www cnbc.com/2016/11/16/chinas-gain-the-collapse-of-the-tpp-could-be-bad-for-everyone.html. Accessed 23 Dec 2016

Schott J (2013) Understanding the trans pacific partnership. In: Schott JJ, Kotschwar B, Muir J (eds) Policy analyses in international economics. Peterson Institute of International Economics, Washington, D.C.

Sumpter M (2016) China's gain? The collapse of the TPP could be bad for everyone. http://www.cnbc.com/2016/11/16/ chinas-gain-the-collapse-of-the-tpp-could-be-bad-for-everyone. Accessed 23 Dec 2016

UN Comtrade, United Nations commodity trade statistics database. http://comtrade.un.org/db. Accessed 15 Nov 2016

World Bank (2016) World development indicators. http://wdi.worldbank.org/table. Accessed 15 Nov 2016

Xin L (2014) A general equilibrium analysis of the TPP free trade agreement with and without China. Margin J Appl Econ Res 8(2):115-136

WTO, I-TIP Goods: Integrated analysis and retrieval of notified non-tariff measures. https://i-tip.wto.org/goods/

Zhai F (2008) Armington Meets Melitz: introducing firm heterogeneity in a global CGE model of trade. J Econ Integr 23:575-604

\section{Submit your manuscript to a SpringerOpen ${ }^{\circ}$} journal and benefit from:

- Convenient online submission

- Rigorous peer review

- Open access: articles freely available online

- High visibility within the field

Retaining the copyright to your article

Submit your next manuscript at $\gg$ springeropen.com 